\title{
Article \\ Efficacy of Bacillus subtilis XZ18-3 as a Biocontrol Agent against Rhizoctonia cerealis on Wheat
}

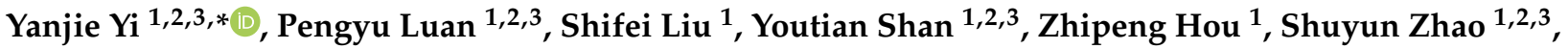 \\ Shao Jia ${ }^{1,2,3}$ and Ruifang $\mathrm{Li}^{1,2,3, *}$
}

check for

updates

Citation: Yi, Y.; Luan, P.; Liu, S.; Shan, Y.; Hou, Z.; Zhao, S.; Jia, S.; Li, R. Efficacy of Bacillus subtilis XZ18-3 as a Biocontrol Agent against Rhizoctonia cerealis on Wheat. Agriculture 2022, 12 , 258. https://doi.org/10.3390/ agriculture12020258

Academic Editors: Francesco Lops and Antonia Carlucci

Received: 31 December 2021

Accepted: 8 February 2022

Published: 11 February 2022

Publisher's Note: MDPI stays neutral with regard to jurisdictional claims in published maps and institutional affiliations.

Copyright: (C) 2022 by the authors. Licensee MDPI, Basel, Switzerland. This article is an open access article distributed under the terms and conditions of the Creative Commons Attribution (CC BY) license (https:// creativecommons.org/licenses/by/ $4.0 /)$.
1 School of Biological Engineering, Henan University of Technology, Zhengzhou 450001, China; 2021920159@stu.haut.edu.cn (P.L.); 201720040312@stu.haut.edu.cn (S.L.); shanyoutian@stu.haut.edu.cn (Y.S.); 2021920170@stu.haut.edu.cn (Z.H.); 202012030321@stu.haut.edu.cn (S.Z.); jiashao@stu.haut.edu.cn (S.J.)

2 The Key Laboratory of Functional Molecules for Biomedical Research, Zhengzhou 450001, China

3 Henan Provincial Key Laboratory of Biological Processing and Nutritional Function of Wheat, Zhengzhou 450001, China

* Correspondence: yiyanjie@haut.edu.cn (Y.Y.); lrf@haut.edu.cn (R.L.); Tel.: +86-371-67756513 (Y.Y. \& R.L.)
Abstract: Rhizoctonia cerealis is a major fungal pathogen of wheat that causes great yield losses in all wheat-growing regions of the world. The biocontrol agent Bacillus subtilis XZ18-3 was investigated for inhibiting $R$. cerealis growth in wheat. The results of the mycelial growth test showed that the sterile filtrate of $B$. subtilis XZ18-3 could significantly inhibit the mycelial growth of $R$. cerealis and cause swelling and rupture of the mycelium. Observation by transmission electron microscopy indicated that the sterile filtrate could penetrate the cellular membrane of Rhizoctonia cerealis, resulting in organelle destruction. The effect of the sterile filtrates on the pathogen cells, shown through fluorescent microscopy using different stains, revealed the mechanism by which the sterile filtrate caused DNA fragmentation, accumulation of ROS and changes in cell membrane permeability. To reach a better treatment of the soil-borne fungi, the components of a wettable powder were screened and an optimised formula determined (30.0\% kaolin, 4.0\% polyvinyl alcohol, 8.0\% Tween-80, 2.0\% polyethylene glycol and $100 \%$ fermentation broth). A quality index analysis revealed that the wetting powder reached acceptable biological pesticide standards. Pot control experiments showed that the wettable powder of B. subtilis XZ18-3 effectively controlled the pathogens with an efficacy of $88.28 \%$. This study has provided the potential biocontrol agents (BCAs) for wheat sharp eyespot disease.

Keywords: action mechanism; Bacillus subtilis; biocontrol agent; Rhizoctonia cerealis; wheat sharp eyespot

\section{Introduction}

Wheat (Triticum aestioum L.) is an important crop in the world and diseases caused by soil-borne pathogens threaten its cultivation [1]. In many regions of the world, wheat production has suffered significant losses due to pathogenic fungi. During the last three decades, plant-pathogenic fungi frequently infect wheat in many countries in Asia, Europe, North America, Africa, and Oceania. The incidence of sharp eyespot infection of wheat has reduced the yield by an average of 5 and 26\% respectively in England and Wales, and also from 20 to 30\% in Egypt and other important economic areas [2]. Wheat sharp eyespot is the main disease affecting wheat cultivation, and is caused by the fungus Rhizoctonia cerealis. It can destroy the transport organization of plants, causing nutrients to be unable to transported to various tissues and cells [3]. Plants may be attacked at any stage of growth, and infection in the early planting period can cause serious damage to seedlings. In recent years, the popularization of high planting density, and high inputs of irrigation and fertilization have accelerated the spread and severity of $R$. cerealis [4]. This pathogen is the most severe biotic stress affecting wheat grain yield in some regions of the world, which seriously reduces crop yield [5]. 
The soil-borne fungus Rhizoctonia cerealis is an anamorphic species in the genus Rhizoctonia (https://gd.eppo.int/taxon/RHIZCE. 3 February 2022) that does not produce asexual spores and survives as sclerotia (small resistant structures) and mycelia in the soil, or in crop residues, and has many host plants, like bermudagrass, barley and corn, but mostly grows in wheat [2]. At the growth stage, the disease can cause cloudy spots on wheat stems, basal rot, seedling blight, and white spikes. The symptoms most frequently observed in mature plants are lesions occurring on the base of stems [6].

Because of the lack of resistant germplasm resources and the loss of variety in resistance, the plant has not been screened worldwide for ideal wheat sharp eyespot disease resistance resource materials [7]. At present, chemical pesticides are still mainly used for preventing and treating soil-borne wheat pathogens. There are several effective fungicides available and labelled for use in wheat crops to control $R$. cerealis, including triazoles, strobilation, biopesticides, etc. [8,9]. However, using chemical pesticides for a long time, may not only increase pathogen resistance to chemicals, but also cause great harm to the human body through respiratory and stomach diseases, etc. [10]. Now, biological control offers an environmentally friendly method by using microbial antagonists against plant pathogens. The disease suppression function of the genus Bacillus occurs via reciprocal inhibition relationships between biological species. Bacillus subtilis is a ubiquitous inhabitant of the soil and is widely recognized as a powerful biological control agent against soil-borne diseases of plants. Therefore, to manage the disease, alternative strategies, such as effective biological control agents (BCAs), are required [11].

It was reported that several biocontrol bacteria have been widely used to prevent and control soil-borne fungal diseases [12-14]. Bacillus subtilis, a non-pathogenic and endophytic bacterium that exists widely in nature, can inhibit a variety of plant diseases [15]. According to related reports, the biocontrol mechanisms of strains of Bacillus subtilis include the production of a wide spectrum of antibiotics, synthesis of extracellular enzymes, competition for nutrients and niches, and induction of systemic resistance in plants against pathogens [16-18]. Using antagonistic bacteria as biocontrol agents represents an effective alternative for agricultural production systems [19]. However, the control of wheat sharp eyespot disease remains challenging despite many efforts to date. Nowadays, research has focused on using microorganisms for the development of novel biocontrol agents.

In an attempt to develop biological control agents (BCAs) for wheat sharp eyespot disease using antagonistic microorganisms, and to further investigate their actions against the pathogenic fungus $R$. cerealis, we focused on the mechanism whereby they affected the fungus to improve the biocontrol performance of BCAs. We prepared a wettable powder, which provides a sustainable means to control $R$. cerealis in wheat, and evaluated its effect as a biological control.

\section{Materials and Methods}

\subsection{Materials}

Bacillus subtilis XZ18-3 was isolated from the soils of Tibet and identified by the morphological and physiological characteristics, and its 16S rDNA sequence (GenBank: MK721058.1). The pathogenic fungus $R$. cerealis was kindly supplied by the Institute of Plant Protection, Henan Academy of Agriculture Sciences. They were stored at $-20{ }^{\circ} \mathrm{C}$ in the School of Biological Engineering, Henan University of Technology. Wheat "Qiule 2122", used in the pot controls, was purchased from Henan Qiule Seeds Technology, Co., Ltd., Zhengzhou, China.

Bacillus subtilis XZ18-3 was inoculated into an optimized fermentation medium (0.5 g glucose, 2 g peptone, $1.25 \mathrm{~g} \mathrm{MgSO}_{4}, 0.2 \mathrm{~g} \mathrm{~K}_{2} \mathrm{HPO}_{4}, 5 \mathrm{~g}$ yeast extract, $100 \mathrm{~mL}$ distilled water, $\mathrm{pH} 7$ ) and cultured for $48 \mathrm{~h}$ at $36^{\circ} \mathrm{C}$ with shaking at $180 \mathrm{rpm}$. Then, the supernatant of the fermentation culture of $B$. subtilis XZ18-3 was filtered through a $0.22 \mu \mathrm{m}$ membrane filter to prepare the sterile filtrates. 


\subsection{Inhibitory Effect of Sterile Filtrates on Mycelia of the Pathogens}

The Oxford cup method was used to determine the effects of sterile filtrates on the growth of mycelia in the pathogen [20]. The morphology of the hyphae was observed under an optical microscope. Antifungal activity was tested with the mycelial growth rate method. In brief, $30 \mu \mathrm{L}$ of different concentrations of sterile filtrate were added respectively and evenly coated onto the potato dextrose agar (PDA) plate. A sterile water treatment was used as a control. A pathogen cake with a diameter of $6 \mathrm{~mm}$ was inoculated onto the centre of the plate and cultured at $28^{\circ} \mathrm{C}$ for $5-7$ days, then the expanded diameter of the pathogen cake was measured. The effective concentration causing 50\% inhibition of mycelial growth $\left(\mathrm{EC}_{50}\right)$ was determined [21]. The percentage of inhibition was calculated according to an independent regression equation. The assays were performed three times with three replicates.

\subsection{Ultrastructural Morphology of Pathogens Treated with Sterile Filtrates}

Mycelia of Rhizoctonia cerealis treated with sterile filtrates were observed using transmission electron microscopy (TEM). The mycelial morphology of R. cerealis was examined using the method described by Dr Sarven, with appropriate modifications [22]. In short, the sterilized cellophane sheets were set on PDA and then about $200 \mu \mathrm{L}$ PDA media was coated on the cellophane sheets. Mycelia of $R$. cerealis with $200 \mu \mathrm{L}$ of sterile filtrates using the Oxford cup method were placed at the ends of the cellophane sheets as the treatment groups. Untreated mycelia served as the control. The mycelia at the edge of the bacteriostatic area were sampled with an inoculation needle and fixed in a $2.5 \% 1 \mathrm{~mL}$ sterile centrifuge tube for the treatment group after $24 \mathrm{~h}$.

\subsection{Effect of Sterile Filtrates on DNA in R. cerealis}

Nuclear fragmentation was detected using DAPI (4',6-diamidino-2-phenylindole) staining. Mycelia were placed in the control group containing only potato dextrose broth (PDB) and the treated groups with sterile filtrates, cultivated for $24 \mathrm{~h}$, washed with phosphate buffered saline (PBS, $0.2 \mathrm{mM}, \mathrm{pH} 7.4$ ), and then fungal mycelia were incubated in PBS supplemented with $10 \mu \mathrm{g} / \mathrm{L}$ DAPI for $15 \mathrm{~min}$ at $28^{\circ} \mathrm{C}$ in the dark. The stained hyphae were then visualized with a fluorescence microscope with an excitation of $364 \mathrm{~nm}$ and emission of $454 \mathrm{~nm}$ [23]. Those with sterile water were used as a control group and those treated with sterile filtrates were used as the treatment groups.

\subsection{Effect of Sterile Filtrates on Reactive Oxygen Species (ROS) in R. cerealis}

Mycelia of $R$. cerealis were treated with sterile filtrates for $24 \mathrm{~h}$. The mycelia were stained with $10 \mu \mathrm{M}$ DCFH-DA solution (Beyotime, Shanghai, China). After incubation at $28^{\circ} \mathrm{C}$ for $30 \mathrm{~min}$ in the darkness, the samples were observed and photographed using fluorescence microscopy [24].

\subsection{Detection of Sterile Filtrates on Cell Membrane Permeability}

The effect of sterile filtrates on cell membrane permeability was examined by propidium iodide (PI) staining as described in a previous study with slight modifications [25]. The effects of sterile filtrates on intracellular leakage were determined using an extracellular conductivity method [26]. The intracellular protein, sugar, and nucleic acid leakage of mycelia were determined by a spectrophotometry method with minor modification [27]. In short, mycelia of $R$. cerealis were treated with sterile filtrates and incubated for $2 \mathrm{~h}, 4 \mathrm{~h}$, $6 \mathrm{~h}, 8 \mathrm{~h}, 24 \mathrm{~h}, 32 \mathrm{~h}, 44 \mathrm{~h}$ at room temperature, and their absorbance measured at $595 \mathrm{~nm}$, $620 \mathrm{~nm}, 260 \mathrm{~nm}$ using a UV-Visible spectrophotometer. A sterile water treatment was used as the control group. Each treatment was replicated thrice, and the experiment was repeated thrice. 


\subsection{Stability Test of the Sterile Filtrates}

The stability of thermal, $\mathrm{pH}$, illuminated light, and UV light were assessed according to the method of improved mycelial growth rate [28,29]. All experiments were performed in triplicate and antifungal activity was determined by the Oxford cup method mentioned above. The antifungal activity of sterile filtrates was calculated using the following equation [24]:

$$
\text { Inhibition rate }(\%)=(\mathrm{CK}-\mathrm{T}) / \mathrm{CK} \times 100
$$

where $\mathrm{T}=$ the mycelial radial growth diameter of the pathogen inhibited by sterile filtrates, $\mathrm{CK}=$ the mycelial radial growth diameter of the pathogen in the control.

\subsection{Screening of Carriers and Auxiliaries for XZ18-3 Wettable Powder}

Common carriers (Kaolin, Talc, Calcium Carbonate), dispersants (Polyvinyl alcohol, Gum Arabic, CMC-Na), wetting agents (SDS, SDBS, Tween-80), stabilizers $\left(\mathrm{K}_{2} \mathrm{HPO}_{4}\right.$, Polyethylene glycol, $\mathrm{K}_{3} \mathrm{PO}_{4}$ ) were screened for suitability. Previously reported methods were performed to identify carriers and excipients [30]. The number of colonies in each medium was recorded. The number of antagonist colonies and suspension rate were used as the final screening criteria to determine the proportion of each component in the wettable powder by orthogonal tests [ $\left.\mathrm{L}_{9}\left(3^{4}\right)\right]$ with the screened carriers and additives [31].

\subsection{Preparation and Quality Test of XZ18-3 Wettable Powder}

The sterile filtrate, the optimized carrier and additives were mixed in a certain ratio, then dried in an oven at $50^{\circ} \mathrm{C}$ until its weight was constant, and finally ground fully with a mortar to make the wettable powder [32]. The detection indices $\mathrm{pH}$, fineness, wet time, suspension rate, and drying loss [31] refer to the standards issued by the Collaborative International Pesticides Analytical Council.

\subsection{Biocontrol Effect of XZ18-3 Wettable Powder in Pot Experiments}

To evaluate the potential of XZ18-3 wettable powder as a biocontrol agent against $R$. cerealis, the incidence index was analysed and determined by potted experiment. Round and full wheat seeds were selected and wetted with distilled water, then soaked for $10 \mathrm{~min}$ with $0.05 \% \mathrm{NaCLO}$ and washed with distilled water 3 times. Cakes of $R$. cerealis and wheat grains were mixed and poured into $9 \mathrm{~cm}$ sterile petri dishes and cultured in a constant temperature incubator at $28^{\circ} \mathrm{C}$ for 5 days.

The biocontrol effect of mycelia was determined by a pot experiment method with minor modification [33]. Water containing mycelium of $R$. cerealis was poured into the planted soil for subsequent wheat seed establishment. The treated wheat seeds were sowed in the pot with 15 seeds in each pot. Twenty days after wheat sprouting, XZ18-3 wettable powder diluted with distilled water 10,50, or 100 times respectively, was applied once every 7 days (a total of 2 times); each treatment was repeated 3 times, and the control group used water. After 30 days, the incidence of wheat sharp eyespot disease was investigated, and the disease index and the relative control effect were calculated according to the following formula [34]:

Disease index $=[(\Sigma$ disease grades $\times$ number of infected plants $) /($ total number of plants $\times 9)] \times 100$

$$
\text { Control efficiency }(\%)=(C K-T) / C K \times 100
$$

where $\mathrm{T}=$ the disease index of treatment, $\mathrm{CK}=$ the disease index of the control.

\subsection{Statistical Analysis}

Statistical analyses of data were performed using the Sigmastat statistical software package (SPSS 14.0, IBM, Chicago, IL, USA). EC $_{50}$ values of the isolates were calculated by linear regression of the log of the colony diameter or zoospore germination versus the fungicide concentrations. When the ANOVA was significant, means were separated with the least significant difference test (LSD, $p=0.05$ ). 


\section{Results}

\subsection{Effect of In Vitro Antifungal Activity}

Plate inhibition experiments showed that both B. subtilis XZ18-3 and its sterile filtrates had an inhibitory effect on $R$. cerealis. It was observed under a microscope that mycelia treated with the sterile filtrates had a significantly increased number of branches, enlarged apical branches and deformed mycelia (Figure 1A). To assess the antifungal activity of the sterile filtrates of strain XZ18-3, their inhibition effect was determined. With an increase in the concentration of the sterile filtrates, the antifungal activity on $R$. cerealis was gradually enhanced. The results showed that the active substances produced by the metabolism of B. subtilis XZ18-3 could inhibit the growth of R. cerealis mycelia (Figure 1B).

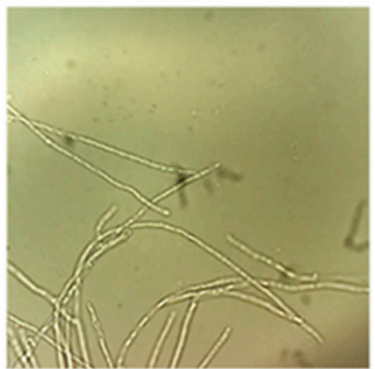

Control

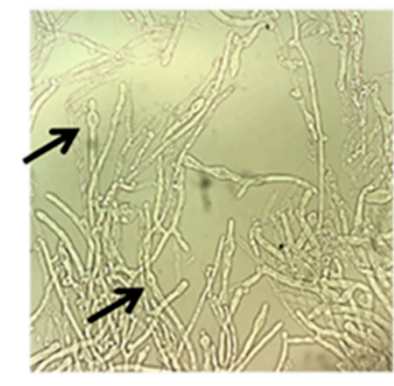

Treatment

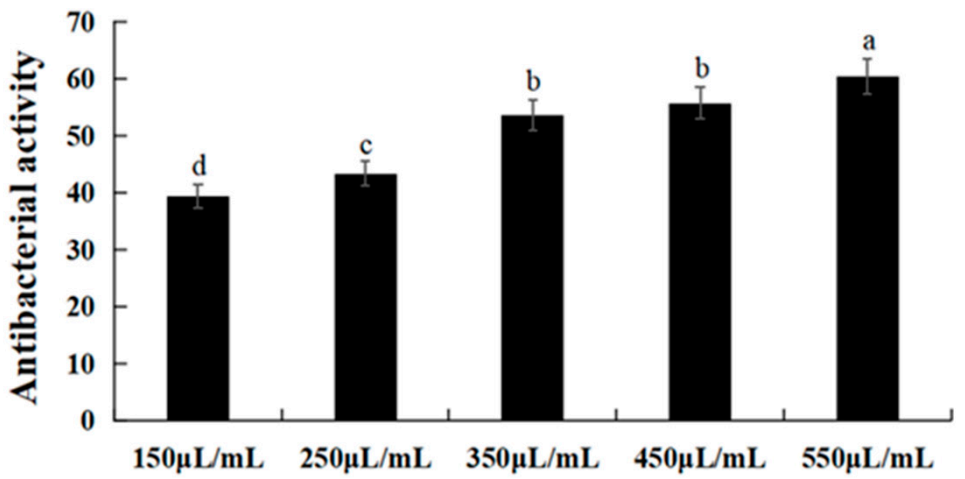

Concentration of the sterile filtrates

(A)

(B)

Figure 1. (A) The number of mycelia in the treated group was observed to increase under the microscope $(\times 40)$; arrow indicates inflated hyphae; $(\mathbf{B})$ The independent regression equation is $y=0.9805 x+2.5565$. The correlation coefficient $\mathrm{R}^{2}=0.9491$. The $\mathrm{EC}_{50}=310.6 \mu \mathrm{L} / \mathrm{mL}$. The error bar represents the standard error of the means of the replicates $(n=3)$. Different letters above the bars indicate significant differences at $p<0.05$ (according to Duncan's multiple range test).

\subsection{Ultrastructural Morphology of Pathogens Mycelia Treated with Sterile Filtrates}

In transverse and longitudinal section, the mycelium cell wall and cell membrane of the control group were closely connected, the structure was complete, the distribution of cell matrix was uniform, and the regular structure of the section was clear (Figure 2). In contrast, the cell membranes of the pathogenic mycelia in the treatment group were rough and blurry. Some organelles disintegrated and formed many blank areas, and some shrank. Abnormal increase of hollow organelles can be seen in the longitudinal section. This suggested that the sterile filtrates can inhibit the growth formation of mycelia.

\subsection{Effect of Sterile Filtrates on DNA Damage in R. cerealis}

DNA damage was assessed by using DAPI staining, and a remarkable increase in the intensity of blue fluorescence was obtained in the treated group, indicating that the sterile filtrates were able to cause nuclear damage within the mycelia, thus disrupting the growth of the mycelia (Figure 3).

\subsection{Effect of Sterile Filtrates on the Production of ROS in R. cerealis}

The intracellular ROS levels in the fungal mycelia were observed using the DCFH-DA staining method. As shown in the Figure 4, the green fluorescence of the treated group was significantly different than that of the control group, indicated that the sterile filtrates may have caused an activity change in the mycelia cells, which resulted in increased levels of reactive oxygen species (ROS) in the mycelia. 


\section{Control}
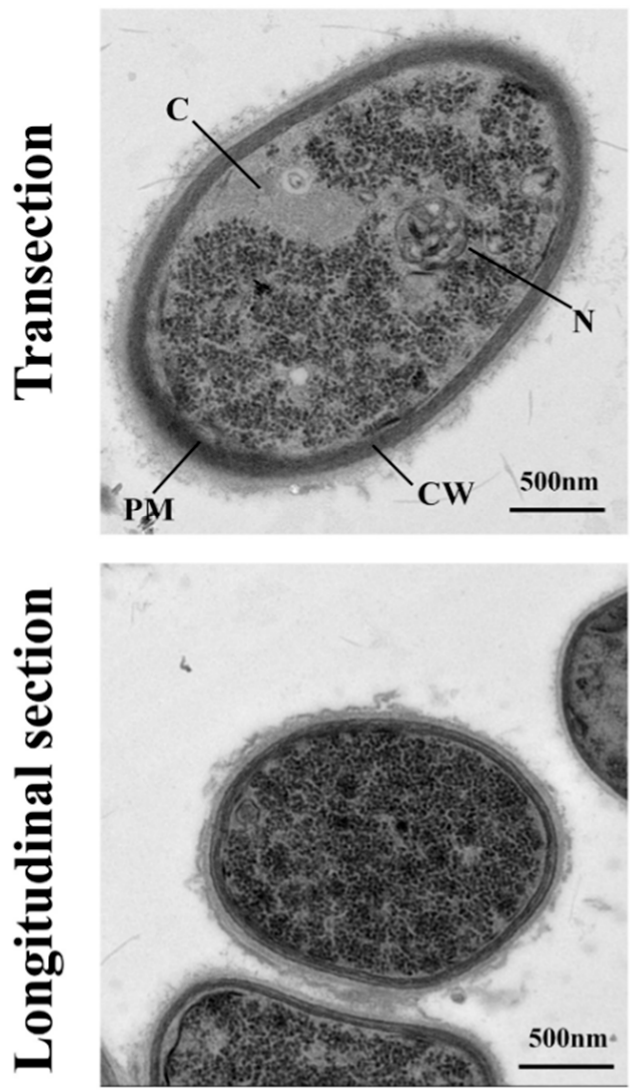

Treatment
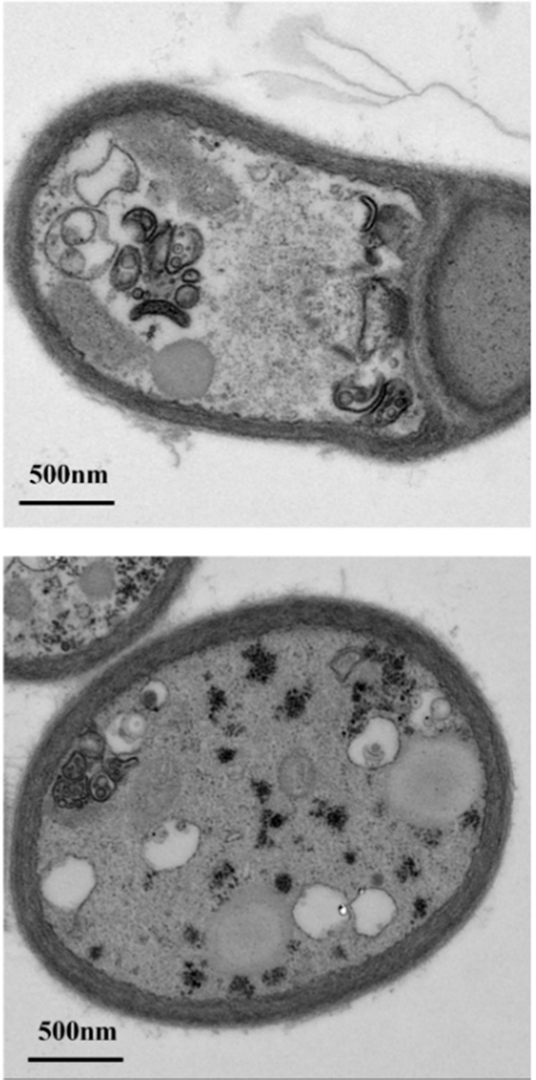

Figure 2. Effects of sterile filtrates on cell ultrastructure of $R$. cerealis viewed with a transmission electron microscope. The group without sterile filtrates was set as the control. Scale bars represent $500 \mathrm{~nm}$. CW, cell wall; PM, plasma membrane; N, nucleus; C, cytosol.

Control
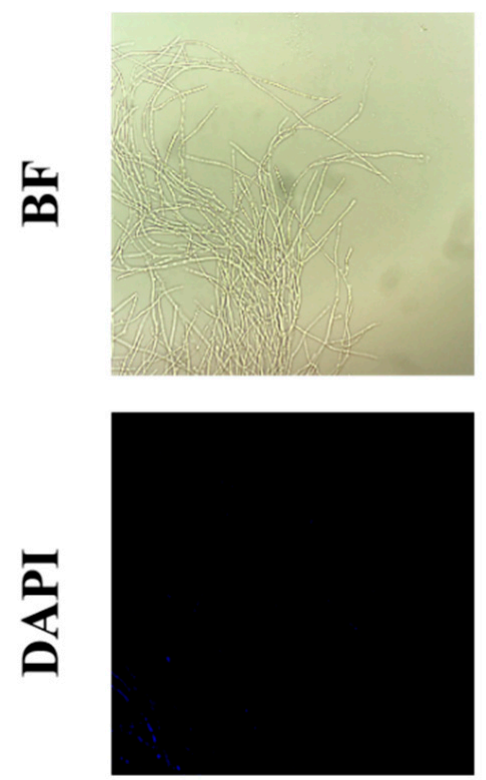

Treatment
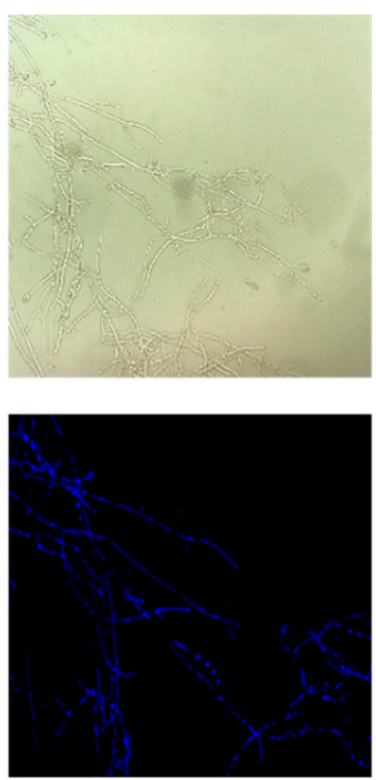

Figure 3. Effect of B. subtilis XZ18-3 sterile filtrates on DNA damage in $R$. cerealis. The fluorescence excitation wavelength is $340 \mathrm{~nm}$. 
Control
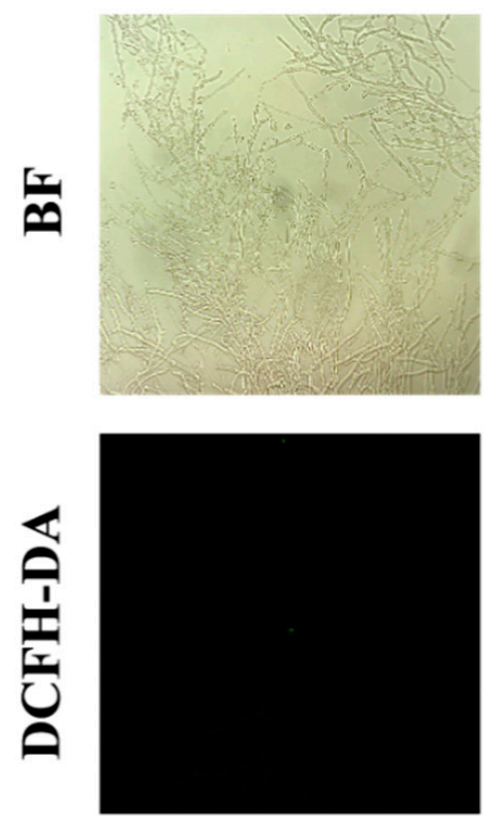

Treatment
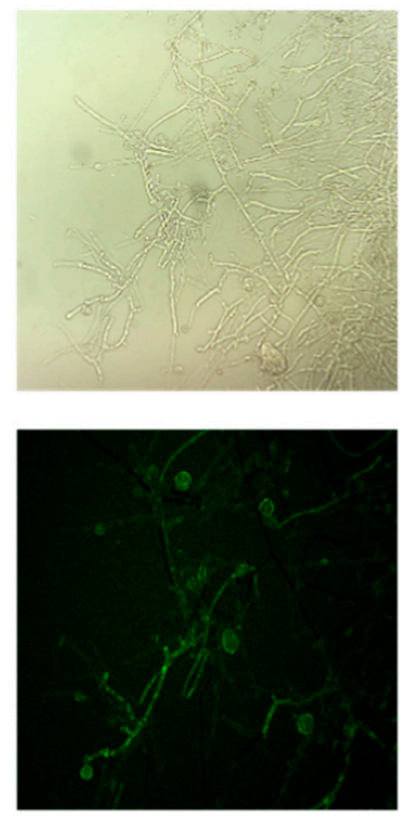

Figure 4. Effect of B. subtilis XZ18-3 sterile filtrates on ROS accumulation in R. cerealis. The fluorescence excitation wavelength is $448 \mathrm{~nm}$.

\subsection{Effect of Sterile Filtrates on the Cell Membrane Permeability of R. cerealis}

To examine the possible mechanisms for the inhibition of mycelial growth in R. cerealis by the sterile filtrates of $B$. subtilis XZ18-3, the condition of the cell membrane of $R$. cerealis was inspected (Figure 5A). Mycelia with damaged cell membranes emitted red fluorescence under fluorescence microscopy, while the fluorescence could not be distinguished from that of mycelia with undamaged cell membranes. And as the concentration increased, the intensity of red fluorescence was stronger, and the mycelium cell membrane was more severely damaged. It showed that the active substances produced by the metabolism of B. subtilis XZ18-3 could damage the cell membrane of pathogenic fungi and lead to the leakage of nucleic acid macromolecules such as DNA and RNA, as well as soluble sugars and protein substances, and inhibit their growth (Figure 5B).

As shown in Figure 5C, the relative conductivity of mycelia of $R$. cerealis increased over time, whether treated with sterile filtrates or not. After treatment with sterile filtrates, the cell membrane permeability was always higher than that of the untreated controls. These results suggested that sterile filtrates might lead to cell membrane damage and mycelia electrolyte leakage increase in $R$. cerealis.

\subsection{Stability Test of the Sterile Filtrates}

The antifungal activity of the sterile filtrate was relatively stable at $37^{\circ} \mathrm{C}$, the inhibition rate decreased as temperature increased, and it was intolerant to high temperature (Figure 6A). Antifungal activity of the sterile filtrate was observed at different $\mathrm{pH}$ values, with peak activity at $\mathrm{pH} 7$, while extreme $\mathrm{pH}$ conditions resulted in decreased antifungal activity (Figure 6B). Sterile filtrates treated with illuminated light were stable in their activity against the pathogen (Figure 6C), and when treated with UV light, were not affected (Figure 6D). 

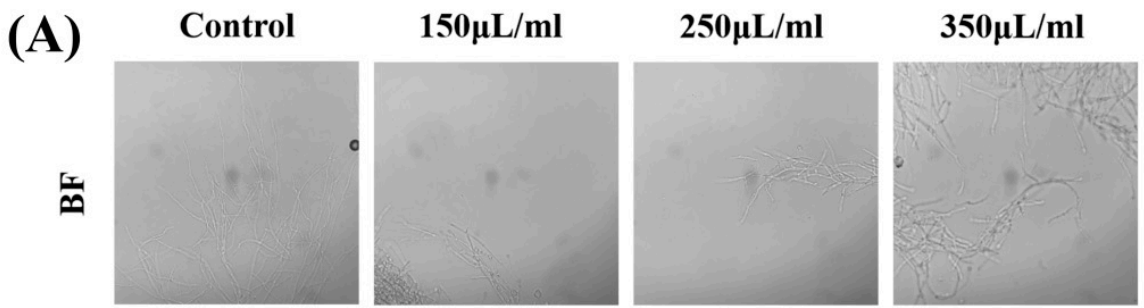

$450 \mu \mathrm{L} / \mathrm{ml}$

$550 \mu \mathrm{L} / \mathrm{ml}$
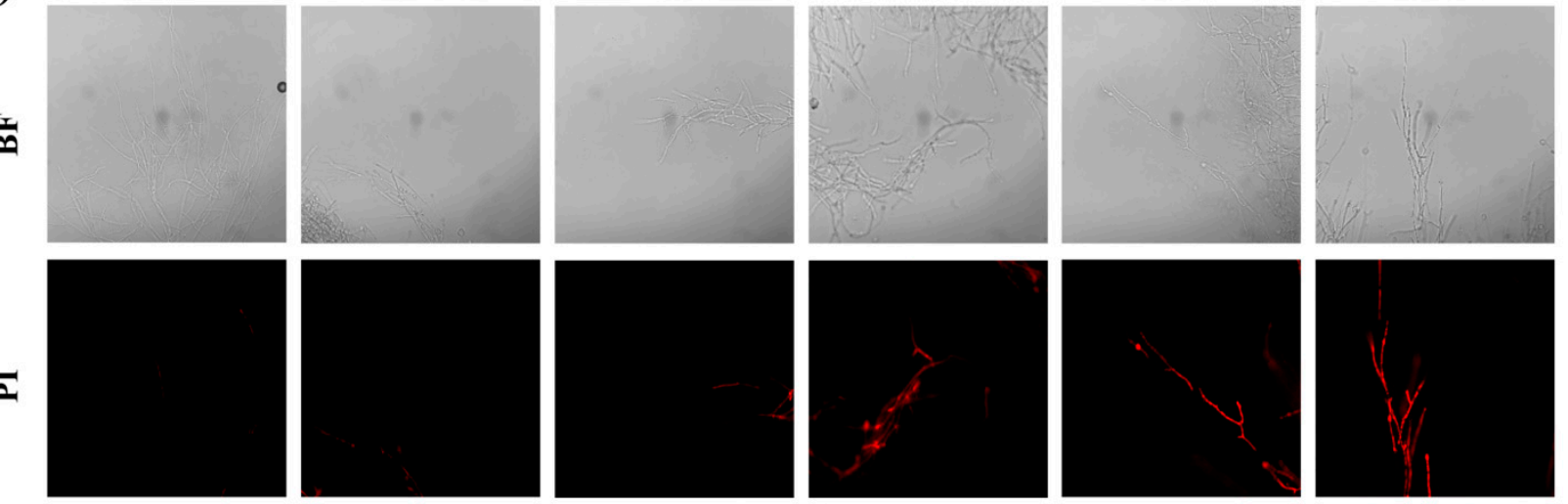

(B)
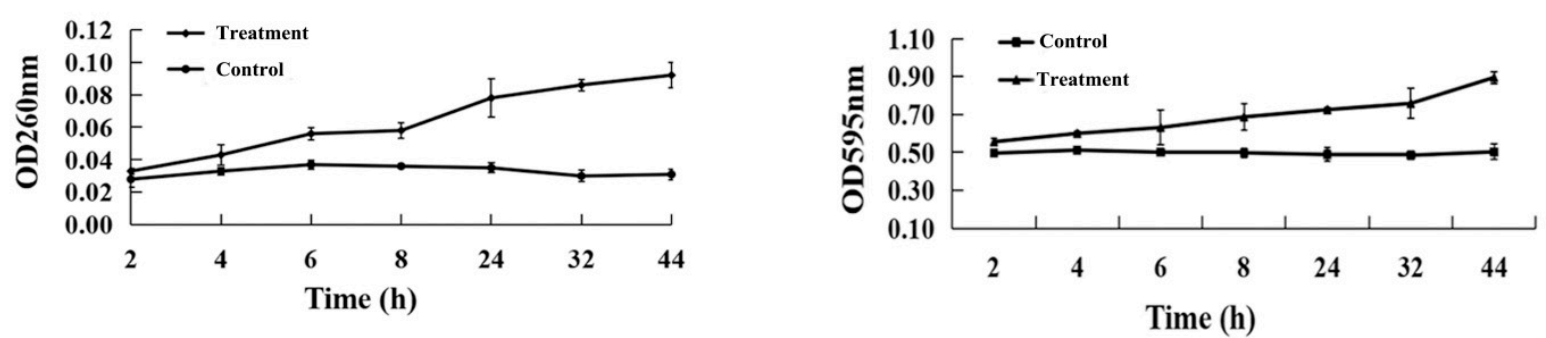

(a)

(b)

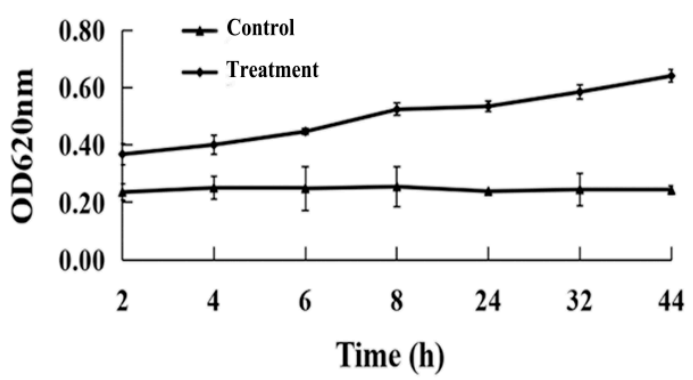

(C)

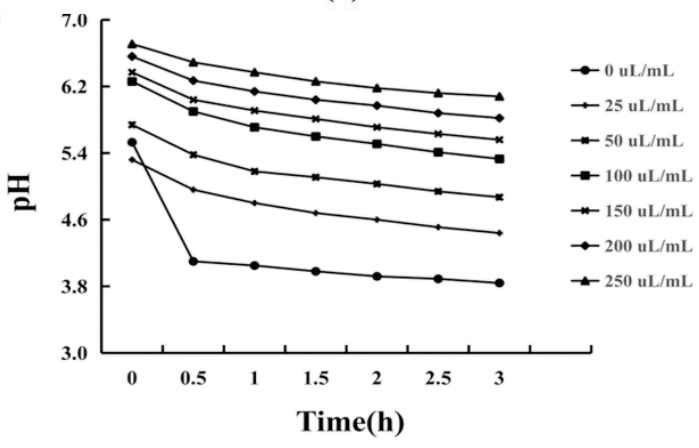

(c)

Figure 5. (A). Effect of sterile filtrates of B. subtilis XZ18-3 on cell membrane integrity in R. cerealis. (B). Effect of B. subtilis XZ18-3 sterile filtrates on release of cell constituents in R. cerealis. (a). $260 \mathrm{~nm}$ nucleic acid substances release. (b). $595 \mathrm{~nm}$ soluble protein release. (c). $620 \mathrm{~nm}$ soluble sugar release. (C). Effect of different concentrations of sterile filtrates on the extracellular $\mathrm{pH}$ of $\mathrm{R}$. cerealis.

\subsection{Screening Results of Wettable Powder}

The effect of different carriers on the activity of B. subtilis XZ18-3 is showed in Figure 7, and according to the results, each carrier had a significant effect on the activity of $B$. subtilis XZ18-3 compared to the control group ( $p<0.05)$. Of the carriers (Figure 7$)$, Kaolin had least effect on the activity of the bacteriophage, is an inert material and is cheap, and can provide some protection from heat for the bacteriophage at higher temperatures, so it was chosen as the carrier. Polyvinyl alcohol had no significant effect on the activity of $B$. subtilis XZ18-3 and had the best suspension effect, so was chosen as the dispersant. Tween-80 had no significant effect $(p>0.05)$ on the activity of $B$. subtilis $X Z 18-3$, so was selected as the wetting agent. Polyethylene glycol had no effect on the activity of B. subtilis XZ18-3, and the number of colonies was almost the same as that of the control group, indicating that its selection as a stabilizer could improve the survival rate of budding spores or bacteria. 

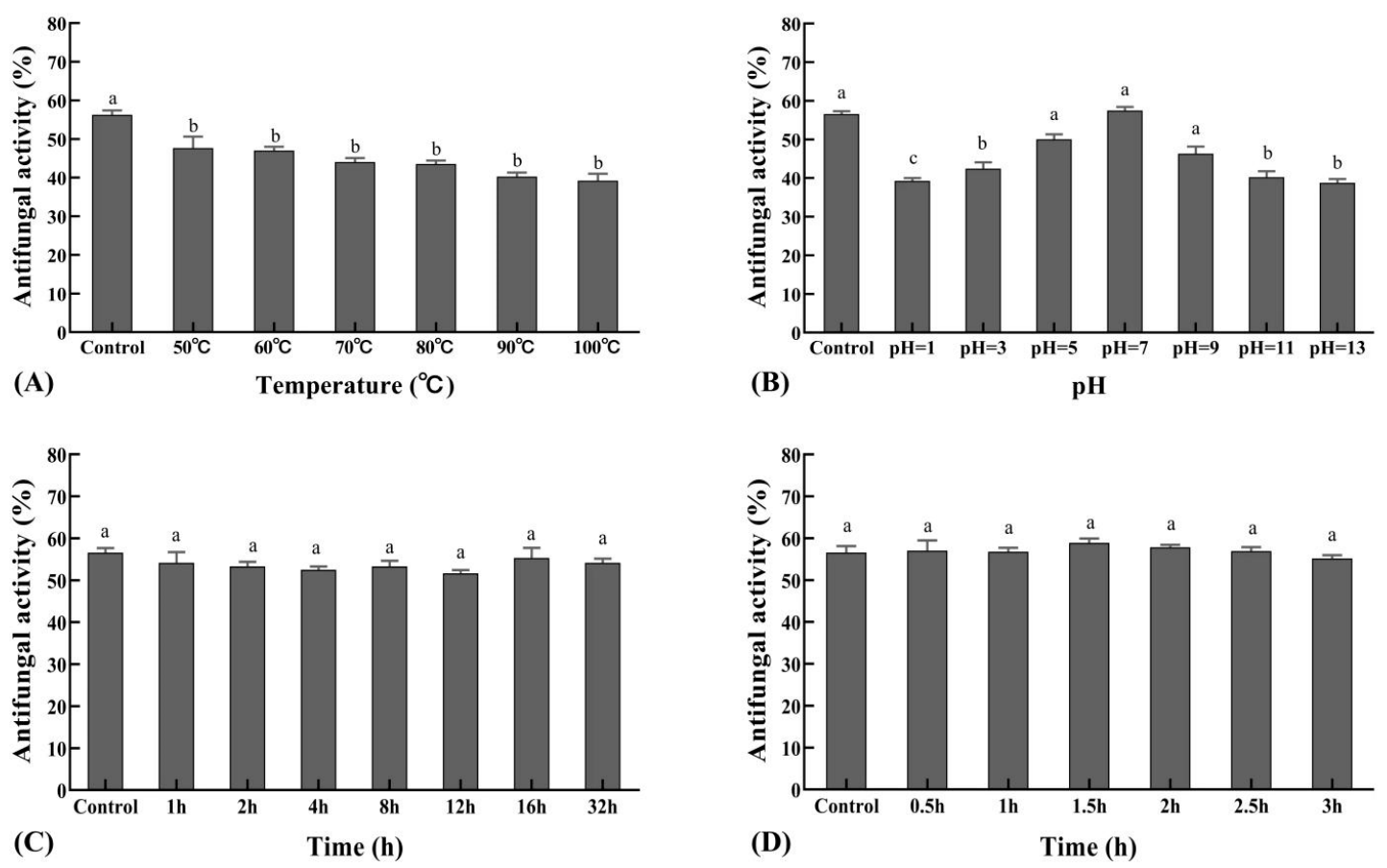

Figure 6. Stability of the sterile filtrate to varying temperature, $\mathrm{pH}, \mathrm{UV}$, and illuminated light. (A). The effect of XZ18-3 sterile filtrate on $R$. cerealis treated under different temperatures. (B). The effect of XZ18-3 sterile filtrate on $R$. cerealis treated under different $\mathrm{pHs}$. (C). The effect of XZ18-3 sterile filtrate on $R$. cerealis treated with $254 \mathrm{~nm}$ UV light for different lengths of time in hours. (D). Effect of XZ18-3 sterile filtrate on $R$. cerealis treated with $4500 \pm 500 \mathrm{~lx}$ illuminated light for different lengths of time in hours. Different letters above the bars indicate significant differences at $p<0.05$ (according to Duncan's multiple range test).

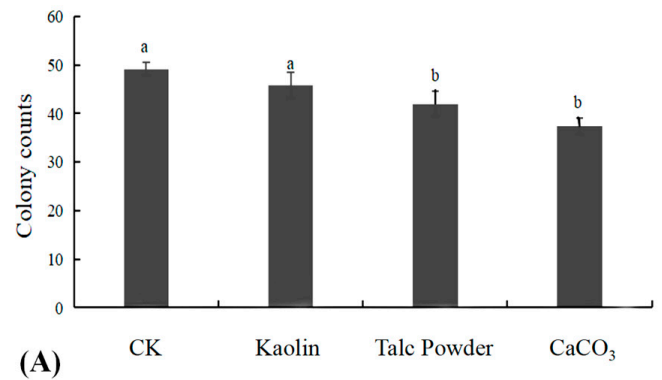

Type of Carrier

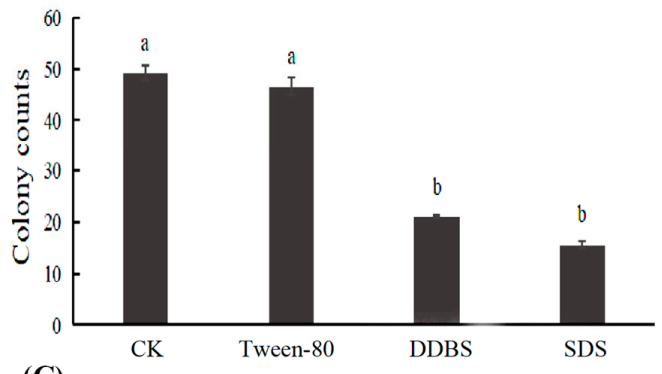

(C)

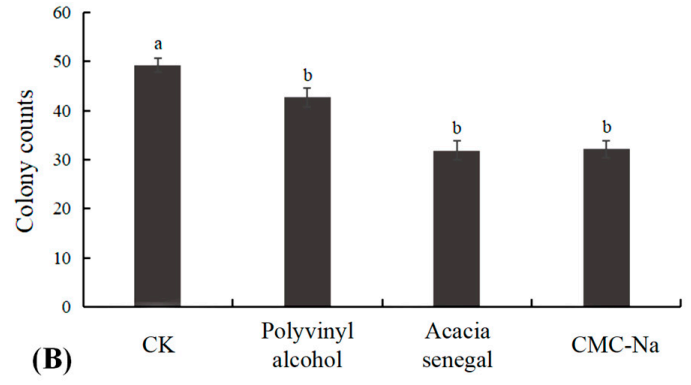

Type of Dispersant

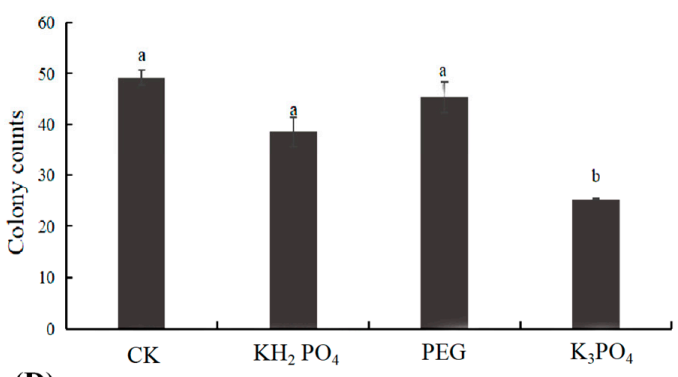

(D)

Type of Wetting powder

Type of Stabilizing agent

Figure 7. (A) The effect of different carriers on biocontrol activity; (B) The effect of different dispersants on biocontrol activity; (C) The effect of different wetting powders on biocontrol activity; (D) The effect of different stabilizing agents on biocontrol activity. Different letters above the bars indicate significant differences at $p<0.05$ (according to Duncan's multiple range test). 
From the Table 1, we can see that the suspension rate $(74.73 \%)$ and colony count were the highest in the second group, so the composition of the wettable powder was chosen to be $30.0 \%$ kaolin, $4.0 \%$ polyvinyl alcohol, $8.0 \%$ Tween- $80,2.0 \%$ polyethylene glycol and $100 \%$ fermentation broth.

Table 1. The optimization ratio of carrier and additive by the orthogonal test.

\begin{tabular}{|c|c|c|c|c|c|c|}
\hline \multirow{2}{*}{ No. } & \multicolumn{4}{|c|}{ Experimental Factor } & \multirow{2}{*}{ Suspension Rate (\%) } & \multirow{2}{*}{ Colony Counts } \\
\hline & Carrier (\%) & Dispersant (\%) & Wetting Agent (\%) & Stabilizer Agent (\%) & & \\
\hline 1 & 30 & 3 & 6 & 1.5 & 65.82 & 48.33 \\
\hline 2 & 30 & 4 & 8 & 2 & 74.73 & 82.62 \\
\hline 3 & 30 & 5 & 10 & 2.5 & 70.51 & 61.33 \\
\hline 4 & 35 & 3 & 8 & 2.5 & 66.99 & 73.51 \\
\hline 5 & 35 & 4 & 10 & 1.5 & 67.74 & 48 \\
\hline 6 & 35 & 5 & 6 & 2 & 68.24 & 24.33 \\
\hline 7 & 40 & 3 & 10 & 2 & 71.73 & 65.4 \\
\hline 8 & 40 & 4 & 6 & 2.5 & 66.37 & 47 \\
\hline 9 & 40 & 5 & 8 & 1.5 & 70.34 & 70.33 \\
\hline
\end{tabular}

\subsection{Quality of Wettable Powder}

The values for quality inspection of wettable powder are showed in Table 2. The suspension rate was $73.60 \%$ (>70\%). The moisture content was $1.01 \%$. The fineness was $96.25 \%$. The wetting time was $54.0 \mathrm{~s}(<180 \mathrm{~s})$ and the $\mathrm{pH}$ was 6.98.

Table 2. Values for quality inspection of wettable powder of B. subtilis XZ18-3.

\begin{tabular}{ccc}
\hline Index & National Standards & Actual Value \\
\hline Suspension rate (\%) & $\geq 70$ & 73.60 \\
Moisture content (\%) & $\leq 4$ & 1.01 \\
Fineness (\%) & $\geq 90$ & 96.25 \\
Wetting time (s) & $\leq 180$ & 54 \\
pH & $5.0-8.0$ & 6.98 \\
\hline
\end{tabular}

\subsection{Effect of XZ18-3 Wettable Powder on the Biocontrol of Wheat Sharp Eyespot Disease}

The control of wheat sharp eyespot disease was tested in pots with different concentrations of B. subtilis XZ18-3 in the wettable powder or a water agent. From Table 3, it is evident that the wettable powder was more effective than the water agent. Therefore, a wettable powder can be developed as a tool for control of this fungus. As the dilution factor of XZ18-3 in the wettable powder increased, the control efficacy gradually decreased and was significantly lower than that of 10 -fold dilution treatment, which had $82.88 \%$ efficacy. The relative control efficacy was $60.29 \%$ with 50 -fold dilution. These results showed that the wettable powder had a good control effect on wheat sharp eyespot disease.

Table 3. Control efficacy of XZ18-3 wettable powder on wheat sharp eyespot disease. Different letters above the bars indicate significant differences at $p<0.05$ (according to Duncan's multiple range test).

\begin{tabular}{ccccc}
\hline \multirow{2}{*}{ Treatment } & \multicolumn{2}{c}{ Wettable Powder } & \multicolumn{2}{c}{ Water Agent } \\
\cline { 2 - 5 } & Disease Index & Control Efficacy (\%) & Disease Index & Control Efficacy (\%) \\
\hline CK & 36.06 & - & 67.41 & - \\
10-fold dilution & 6.17 & $82.88 \mathrm{~A}$ & 17.04 & $74.32 \mathrm{~A}$ \\
50-fold dilution & 14.32 & $60.29 \mathrm{~A}$ & 32.59 & $51.65 \mathrm{~A}$ \\
100-fold dilution & 20.00 & $44.54 \mathrm{~B}$ & 50.37 & $25.27 \mathrm{~B}$ \\
\hline
\end{tabular}

\section{Discussion}

In recent years, the use of Bacillus subtilis for the biological control of plant diseases have been carried out extensively. Some reports have pointed out that B. subtilis has the po- 
tential to produce many antimicrobial substances and could inhibit the growth of pathogens and the germination of spores $[35,36]$. Understanding the mode of action between $B$. subtilis and $R$. cerealis is important for developing B. subtilis as a reliable biological control agent.

In this research, the interaction between $B$. subtilis and pathogens was studied for the purpose of evaluating a potential biocontrol mechanism for wheat sharp eyespot disease. Many reports have indicated that inhibition of hyphal growth is the main way of reducing diseases for crops. For example, studies of Zheng et al. showed that B. velezensis D61-A had inhibited hyphal growth in Rhizoctonia solani with an inhibition rate of $80.1 \%$ [37]. Bacillus subtilis SG6 could effectively inhibit both growth and sporulation of F. graminearum [38]. Besides, B. subtilis TE3 could inhibit mycelia growth in B. sorokiniana through culture filtrate [39]. Hyphal growth is a typical feature of filamentous fungi and is an essential requirement for fungal pathogenicity [40]. In our study, sterile filtrates of B. subtilis XZ183 showed high antifungal activity against $R$. cerealis and the inhibition effect increased significantly with their increased concentration. Chen et al. [41] reported that endophytic B. subtilis EDR4 caused abnormal swelling of mycelia in Sclerotinia sclerotiorum. Our results showed by optical microscopy that sterile filtrates of Bacillus subtilis XZ18-3 caused increased mycelia swelling and branching.

Previous studies have shown that biological control approaches for plant diseases include the reduction in the effect of pathogens through different mechanisms, such as competition (for space; for $\mathrm{C}, \mathrm{N}$, or mineral sources), antibiosis (antibiotics, volatile compounds (ammonia, cyanide, alcohols, esters, ketones, enzymes etc.), hyper parasitism, cross-protection, resistance induction, and growth improvement [42-44]. The antifungal effects might have been attributed to one or more antifungal compounds produced by this biocontrol agent. Strain Em7 of B. subtilis could induce the morphological changes by a metabolite of strain Em7 in the hyphal cells of plant pathogens [45]. Through TEM observation, we observed suppression of fungal growth was associated with the degeneration of fungal hypha after treatment. These degeneration modifications mainly included cytoplasmic coagulation, vacuolations, organelles disintegration, and rough plasma membranes. The results suggest that $B$. subtilis XZ18-3 can interfere with the normal mycelial growth.

Based on the above results, we inferred that the membrane permeability of the treated cell was altered, and that intracellular changes occurred. The changes in the treated hyphal cells may be a result of indirect effects or comprehensive effects of multiple factors by the sterile filtrates of $B$. subtilis XZ18-3. The most important structure in the nucleus is chromatin, and its components are protein molecules and DNA molecules. Such Bacillusbased sterile filtrates could cause damage to the cells of pathogens and result in the alteration of cell morphologies and structures, or in apoptosis and necrosis, in a filamentous fungus [46,47]. The study of Li et al. [47] indicated that the B. cereus strain B-02 might influence the synthesis of DNA and hyphal cell apoptosis. Another study indicated that the Bacillus amyloliquefaciens strain JCK-12 produced CLPs to alter the cell membrane permeability of F. graminearum [25]. Reactive oxygen was one of the main factors inducing cell apoptosis and its generation is an important marker of oxidative stress [48,49]. From the fluorescent staining observations and the measurement of the release of soluble substances by leakage, it can be tentatively determined that the sterile filtrates of $B$. subtilis XZ18-3 were able to disrupt the cell membrane, cause DNA destruction in $R$. cerealis, resulting in the leakage of soluble macromolecules from the cell. The extracellular $\mathrm{pH}$ value also confirmed that the membrane permeability of the treated cell was influenced. So, we concluded that sterile filtrates of $B$. subtilis XZ18-3 interfere with the membrane integrity and may induce cell death in the pathogen $R$. cerealis.

In this study, the stability of the culture filtrate activity was determined at various temperatures, $\mathrm{pH}$, and treatments of illuminated light and UV light. At $37^{\circ} \mathrm{C}$, the antifungal activity of sterile filtrate of the $B$. subtilis XZ18-3 remained higher, however the activity was decreased with temperature increase, but not significantly so. Values for $\mathrm{pH}$ above and lower than 7.0 were not stable. Activity in the treatment group with illuminated light or UV light for a long time were stable. So, the sterile filtrates were intolerant to high temperature 
and $\mathrm{pH}$, but tolerant to UV and sunlight. Taswar Ahsan et al. [28] reported stability of antifungal filtrate at different temperature and $\mathrm{pH}$ values. Because antifungal strains are different, their stability varies. This provides a theoretical basis for follow-up research and has good development potential in application prospects.

In addition, Bacillus-based products play important roles in developing low toxicity biocontrol pesticides and green agriculture [50]. Formulation of biocontrol agents that are stable and efficient are key aspects of biological control [51]. Formulation of biocontrol agents has used aqueous suspensions, wettable powders, oil flowables, etc. [52,53]. The screened ingredients were prepared as a B. subtilis XZ18-3 wettable powder with the formula $30.0 \%$ kaolin, $4.0 \%$ polyvinyl alcohol, $8.0 \%$ Tween- 80 , $2.0 \%$ polyethylene glycol and $100 \%$ fermentation broth. Some studies have pointed out that wettable powder overcome the disadvantages of the liquid agent because the main growth form of pathogens are mycelia, and the powders are more stable [53]. To date, B. subtilis QST713 and B. subtilis MBI600, which is a commercial biocontrol agent, have been used to control pathogens in crops like soybeans, vegetables and fruits etc $[54,55]$. The performance indices (suspension rate as $73.60 \%$, moisture content as $1 \%$, fineness as $96.25 \%$, the wetting time as $54 \mathrm{~s}$ and $\mathrm{pH}$ as 6.98) all conform to the quality requirements of a pesticide wettable powder, which would provide a basis for the investigation of actual formulations. Pot control tests showed that the control efficacy of XZ18-3 wettable powder diluted 10-fold on wheat sharp eyespot disease reached $82.88 \%$. Thus, it is recommended to use a XZ18-3 wettable powder dilution of 10-fold for control of wheat sharp eyespot disease. However, mass production processes need to be further studied. Bacillus subtilis has been considered as a promising source for the development of BCAs against phytopathogens, as they exhibit beneficial functions towards host plants [56]. The development of BCAs is an important feature of commercial preparations for sustainable agriculture [57]. Therefore, XZ18-3 should be a potential candidate for application as a biological control agent against $B$. cerealis for controlling wheat sharp eyespot disease.

\section{Conclusions}

Sterile filtrates of Bacillus subtilis XZ18-3 had good inhibition effects on the mycelial growth of $R$. cerealis and caused swelling and rupture of the mycelium. Sterile filtrates could penetrate the cellular membrane of $R$. cerealis and lead to organelle destruction. The effect of sterile filtrates on pathogen cells, demonstrated through fluorescent microscopy using different stains, revealed the mechanism which by which they can cause DNA fragmentation, changes of cell membrane permeability and accumulation of ROS. Through screening and orthogonal optimization, a XZ18-3 wettable powder was prepared with the formula $30.0 \%$ kaolin, $4.0 \%$ polyvinyl alcohol, 8.0\% Tween-80, 2.0\% polyethylene glycol and $100 \%$ fermentation broth, and its indices were evaluated and found to conform to the quality requirements of a pesticide wettable powder. The wettable powder of $B$. subtilis XZ18-3 made an effective control for pathogens with an efficacy of $88.28 \%$, which provides an eco-friendly approach to control $R$. cerealis on wheat and lays the technical foundation for sustainable agriculture.

Author Contributions: Y.Y. and P.L. wrote the manuscript; Y.Y., P.L. and S.L. designed this research; P.L., Y.S., S.L., S.Z. and S.J. performed the experiments; P.L., S.L. and Z.H. made the data analysis. Y.Y. and R.L. revised the manuscript. All authors have read and agreed to the published version of the manuscript.

Funding: This work was supported by China Agriculture Research System of MOF and MARA(CARS03), the National Key Research and Development Program (2017YFC1600601) and the Innovative Funds Plan of Henan University of Technology (2020ZKCJ23).

Institutional Review Board Statement: Not applicable.

Informed Consent Statement: Not applicable.

Data Availability Statement: Not applicable. 
Conflicts of Interest: The authors declare no conflict of interest.

\section{References}

1. Saur, I.; Bauer, S.; Lu, X.; Schulze-Lefert, P. A cell death assay in barley and wheat protoplasts for identification and validation of matching pathogen AVR effector and plant NLR immune receptors. Plant Methods 2019, 15, 118. [CrossRef] [PubMed]

2. Hamada, M.S.; Yin, Y.; Chen, H.; Ma, Z. The escalating threat of Rhizoctonia cerealis, the causal agent of sharp eyespot in wheat. Pest Manag. Sci. 2011, 67, 1411-1419. [CrossRef] [PubMed]

3. Wang, M.; Zhu, X.; Wang, K.; Lu, C.; Luo, M.; Shan, T.; Zhang, Z. A wheat caffeic acid 3-O-methyltransferase TaCOMT-3D positively contributes to both resistance to sharp eyespot disease and stem mechanical strength. Sci. Rep. 2018, 8, 6543. [CrossRef] [PubMed]

4. Kazan, K.; Gardiner, D.M. Fusarium crown rot caused by Fusarium pseudograminearum in cereal crops: Recent progress and future prospects. Mol. Plant Pathol. 2018, 19, 1547-1562. [CrossRef] [PubMed]

5. Zhao, X.; Song, P.; Hou, D.; Li, Z.; Hu, Z. Antifungal activity, identification and biosynthetic potential analysis of fungi against Rhizoctonia cerealis. Ann. Microbiol. 2021, 71, 41. [CrossRef]

6. Rong, W.; Luo, M.; Shan, T.; Wei, X.; Du, L.; Xu, H.; Zhang, Z. A Wheat cinnamyl alcohol dehydrogenase TaCAD12 contributes to host resistance to the Sharp Eyespot disease. Front. Plant Sci. 2016, 7, 1723. [CrossRef]

7. Wang, H.; Shi, Y.; Wang, D.; Yao, Z.; Wang, Y.; Liu, J.; Zhang, S.; Wang, A. A biocontrol strain of Bacillus subtilis WXCDD105 used to control tomato Botrytis cinerea and Cladosporium fulvum cooke and promote the growth of seedlings. Int. J. Mol. Sci. 2018, 19, 1371. [CrossRef]

8. Peng, D.; Li, S.; Wang, J.; Chen, C.; Zhou, M. Integrated biological and chemical control of rice sheath blight by Bacillus subtilis NJ-18 and jinggangmycin. Pest Manag. Sci. 2014, 70, 258-263. [CrossRef]

9. Marx-Stoelting, P.; Knebel, C.; Braeuning, A. The connection of Azole fungicides with Xeno-sensing nuclear receptors, drug metabolism and hepatotoxicity. Cells 2020, 9, 1192. [CrossRef]

10. Martínez-Salgado, S.J.; Andrade-Hoyos, P.; Parraguirre Lezama, C.; Rivera-Tapia, A.; Luna-Cruz, A.; Romero-Arenas, O. Biological control of charcoal rot in peanut crop through strains of Trichoderma spp., in Puebla, Mexico. Plants 2021, 10, 2630. [CrossRef]

11. Kavitha, S.; Senthilkumar, S.; Gnanamanickam, S.; Inayathullah, M.; Jayakumar, R. Isolation and partial characterization of antifungal protein from Bacillus polymyxa strain VLB16. Process Biochem. 2005, 40, 3236-3243. [CrossRef]

12. Yi, Y.; Shan, Y.; Liu, S.; Yang, Y.; Liu, Y.; Yin, Y.; Hou, Z.; Luan, P.; Li, R. Antagonistic strain Bacillus amyloliquefaciens XZ34-1 for controlling Bipolaris sorokiniana and promoting growth in wheat. Pathogens 2021, 10, 1526. [CrossRef] [PubMed]

13. Wang, R.; Wang, C.; Zuo, B.; Liang, X.; Zhang, D.; Liu, R.; Yang, L.; Lu, B.; Wang, X.; Gao, J. A novel biocontrol strain Bacillus amyloliquefaciens FS6 for excellent control of gray mold and seedling diseases of ginseng. Plant Dis. 2021, 105, 1926-1935. [CrossRef] [PubMed]

14. Yang, L.; Quan, X.; Xue, B.; Goodwin, P.H.; Lu, S.; Wang, J.; Du, W.; Wu, C. Isolation and identification of Bacillus subtilis strain YB-05 and its antifungal substances showing antagonism against Gaeumannomyces graminis var. tritici. Biol. Control 2015, 85, 52-58. [CrossRef]

15. Yi, Y.; Li, Z.; Song, C.; Kuipers, O.P. Exploring plant-microbe interactions of the rhizobacteria Bacillus subtilis and Bacillus mycoides by use of the CRISPR-Cas9 system. Environ. Microbiol. 2018, 20, 4245-4260. [CrossRef]

16. Aftab, M.N.; Ikram-Ul-Haq; Baig, S. Systematic mutagenesis method for enhanced production of bacitracin by Bacillus licheniformis Mutant strain UV-MN-HN-6. Braz. J. Microbiol. 2012, 43, 78-88. [CrossRef]

17. Wang, W.; Hollmann, R.; Deckwer, W.D. Comparative proteomic analysis of high cell density cultivations with two recombinant Bacillus megaterium strains for the production of a heterologous dextransucrase. Proteome Sci. 2006, 4, 19. [CrossRef]

18. Li, Y.; Heloir, M.C.; Zhang, X.; Geissler, M.; Trouvelot, S.; Jacquens, L.; Henkel, M.; Su, X.; Fang, X.; Wang, Q.; et al. Surfactin and fengycin contribute to the protection of a Bacillus subtilis strain against grape downy mildew by both direct effect and defence stimulation. Mol. Plant Pathol. 2019, 20, 1037-1050. [CrossRef]

19. Hu, Y.; Li, Y.; Yang, X.; Li, C.; Wang, L.; Feng, J.; Chen, S.; Li, X.; Yang, Y. Effects of integrated biocontrol on bacterial wilt and rhizosphere bacterial community of tobacco. Sci. Rep. 2021, 11, 2653. [CrossRef]

20. Ma, Y.N.; Chen, C.J.; Li, Q.Q.; Xu, F.R.; Cheng, Y.X.; Dong, X. Monitoring Antifungal agents of Artemisia annua against Fusarium oxysporum and Fusarium solani, associated with Panax notoginseng root-rot disease. Molecules 2019, 24, 213. [CrossRef]

21. Shentu, X.; Zhan, X.; Ma, Z.; Yu, X.; Zhang, C. Antifungal activity of metabolites of the endophytic fungus Trichoderma brevicompactum from garlic. Braz. J. Microbiol. 2014, 45, 248-254. [CrossRef] [PubMed]

22. Sarven, M.S.; Hao, Q.; Deng, J.; Yang, F.; Wang, G.; Xiao, Y.; Xiao, X. Biological control of tomato gray mold caused by Botrytis Cinerea with the entomopathogenic fungus Metarhizium anisopliae. Pathogens 2020, 9, 213. [CrossRef]

23. Li, S.; Zhang, S.; Zhai, H.; Lv, Y.; Hu, Y.; Cai, J. Hexanal induces early apoptosis of Aspergillus flavus conidia by disrupting mitochondrial function and expression of key genes. Appl. Microbiol. Biot. 2021, 105, 6871-6886. [CrossRef]

24. Zeng, J.; Zhang, Z.; Zhu, Q.; Jiang, Z.; Zhong, G. Simplification of natural beta-carboline alkaloids to obtain indole derivatives as potent fungicides against rice sheath blight. Molecules 2020, 25, 1189. [CrossRef] [PubMed]

25. Kim, K.; Lee, Y.; Ha, A.; Kim, J.I.; Park, A.R.; Yu, N.H.; Son, H.; Choi, G.J.; Park, H.W.; Lee, C.W.; et al. Chemosensitization of Fusarium graminearum to chemical fungicides using cyclic lipopeptides produced by Bacillus amyloliquefaciens strain JCK-12. Front. Plant Sci. 2017, 8, 2010. [CrossRef] [PubMed] 
26. Tao, N.; Jia, L.; Zhou, H. Anti-fungal activity of Citrus reticulata Blanco essential oil against Penicillium italicum and Penicillium digitatum. Food Chem. 2014, 153, 265-271. [CrossRef]

27. Fleißner, A.; Glass, N.L. SO, a protein involved in hyphal fusion in Neurospora crassa, localizes to septal plugs. Eukaryot. Cell 2007, 6, 84-94. [CrossRef]

28. Ahsan, T.; Chen, J.; Zhao, X.; Irfan, M.; Wu, Y. Extraction and identification of bioactive compounds (eicosane and dibutyl phthalate) produced by Streptomyces strain KX852460 for the biological control of Rhizoctonia solani AG-3 strain KX852461 to control target spot disease in tobacco leaf. AMB Express 2017, 7, 54. [CrossRef]

29. Mendo, S.; Faustino, N.A.; Sarmento, A.C.; Amado, F.; Moir, A.J. Purification and characterization of a new peptide antibiotic produced by a thermotolerant Bacillus licheniformis strain. Biotechnol. Lett. 2004, 26, 115-119. [CrossRef]

30. Crijns, A.P.; Gerbens, F.; Plantinga, A.E.; Meersma, G.J.; de Jong, S.; Hofstra, R.M.; de Vries, E.G.; van der Zee, A.G.; de Bock, G.H.; Te, M.G. A biological question and a balanced (orthogonal) design: The ingredients to efficiently analyze two-color microarrays with confirmatory factor analysis. BMC Genom. 2006, 7, 232. [CrossRef]

31. Zeng, Y.; Liu, H.; Zhu, T.; Han, S.; Li, S. Preparation of nanomaterial wettable powder formulations of antagonistic bacteria from Phellodendron chinense and the biological control of Brown Leaf Spot disease. Plant Pathol. J. 2021, 37, 215-231. [CrossRef] [PubMed]

32. Liu, J.; He, Y.; Chen, S.; Xiao, Y.; Hu, M.; Zhong, G. Development of a freeze-dried fungal wettable powder preparation able to biodegrade chlorpyrifos on vegetables. PLoS ONE 2014, 9, e103558. [CrossRef] [PubMed]

33. Wang, Y.; Sun, Y.; Zhang, Y.; Zhang, X.; Feng, J. Antifungal activity and biochemical response of cuminic acid against Phytophthora capsici Leonian. Molecules 2016, 21, 756. [CrossRef] [PubMed]

34. Han, L.B.; Li, Y.B.; Wang, F.X.; Wang, W.Y.; Liu, J.; Wu, J.H.; Zhong, N.Q.; Wu, S.J.; Jiao, G.L.; Wang, H.Y.; et al. The cotton apoplastic protein CRR1 stabilizes Chitinase 28 to facilitate defense against the fungal pathogen Verticillium dahliae. Plant Cell 2019, 31, 520-536. [CrossRef] [PubMed]

35. Su, Z.; Chen, X.; Liu, X.; Guo, Q.; Li, S.; Lu, X.; Zhang, X.; Wang, P.; Dong, L.; Zhao, W.; et al. Genome mining and UHPLC-QTOFMS/MS to identify the potential antimicrobial compounds and determine the specificity of biosynthetic gene clusters in Bacillus subtilis NCD-2. BMC Genom. 2020, 21, 767. [CrossRef]

36. Sansinenea, E.; Ortiz, A. Secondary metabolites of soil Bacillus spp. Biotechnol. Lett. 2011, 33, 1523-1538. [CrossRef]

37. Zheng, T.; Liu, L.; Nie, Q.; Hsiang, T.; Sun, Z.; Zhou, Y. Isolation, identification and biocontrol mechanisms of endophytic bacterium D61-A from Fraxinus hupehensis against Rhizoctonia solani. Biol. Control 2021, 158, 104621. [CrossRef]

38. Zhao, Y.; Selvaraj, J.N.; Xing, F.; Zhou, L.; Wang, Y.; Song, H.; Tan, X.; Sun, L.; Sangare, L.; Folly, Y.M.E. Antagonistic action of Bacillus subtilis strain SG6 on Fusarium graminearum. PLoS ONE 2014, 9, e92486. [CrossRef]

39. Villa-Rodriguez, E.; Parra-Cota, F.; Castro-Longoria, E.; López-Cervantes, J.; de Los Santos-Villalobos, S. Bacillus subtilis TE3: A promising biological control agent against Bipolaris sorokiniana, the causal agent of spot blotch in wheat (Triticum turgidum L. subsp. durum). Biol. Control 2019, 132, 135-143. [CrossRef]

40. Steinberg, G. Hyphal growth: A tale of motors, lipids, and the spitzenkorper. Eukaryot. Cell 2007, 6, 351-360. [CrossRef]

41. Chen, Y.; Gao, X.; Chen, Y.; Qin, H.; Huang, L.; Han, Q. Inhibitory efficacy of endophytic Bacillus subtilis EDR4 against Sclerotinia sclerotiorum on rapeseed. Biol. Control 2014, 78, 67-76. [CrossRef]

42. Cob-Calan, N.N.; Chi-Uluac, L.A.; Ortiz-Chi, F.; Cerqueda-Garcia, D.; Navarrete-Vazquez, G.; Ruiz-Sanchez, E.; HernandezNunez, E. Molecular docking and dynamics simulation of protein beta-Tubulin and antifungal cyclic lipopeptides. Molecules 2019, 24, 3387. [CrossRef] [PubMed]

43. Wu, Y.; Zhou, J.; Li, C.; Ma, Y. Antifungal and plant growth promotion activity of volatile organic compounds produced by Bacillus amyloliquefaciens. Microbiologyopen 2019, 8, e813. [CrossRef] [PubMed]

44. Yan, F.; Yu, Y.; Gozzi, K.; Chen, Y.; Guo, J.H.; Chai, Y. Genome-wide investigation of biofilm formation in Bacillus cereus. Appl. Environ. Microbiol. 2017, 83, e00561-17. [CrossRef] [PubMed]

45. Gao, X.; Han, Q.; Chen, Y.; Qin, H.; Huang, L.; Kang, Z. Biological control of oilseed rape Sclerotinia stem rot by Bacillus subtilis strain Em7. Biocontrol Sci. Technol. 2014, 24, 39-52. [CrossRef]

46. Tang, Q.; Bie, X.; Lu, Z.; Lv, F.; Tao, Y.; Qu, X. Effects of fengycin from Bacillus subtilis fmbJ on apoptosis and necrosis in Rhizopus stolonifer. J. Microbiol. 2014, 52, 675-680. [CrossRef]

47. Li, F.; Ma, H.; Liu, J.; Zhang, C. Antagonistic Effects of Bacillus cereus strain B-02 on morphology, ultrastructure and cytophysiology of Botrytis cinerea. Pol. J. Microbiol. 2012, 61, 119-128. [CrossRef]

48. Guan, B.; Lin, Z.; Liu, D.; Li, C.; Zhou, Z.; Mei, F.; Li, J.; Deng, X. Effect of waterlogging-induced autophagy on programmed cell death in Arabidopsis Roots. Front. Plant Sci. 2019, 10, 468. [CrossRef]

49. Gong, A.; Li, H.; Yuan, Q.; Song, X.; Yao, W.; He, W.; Zhang, J.; Liao, Y. Antagonistic mechanism of iturin A and plipastatin A from Bacillus amyloliquefaciens S76-3 from wheat spikes against Fusarium graminearum. PLoS ONE 2015, 10, e116871. [CrossRef]

50. Schisler, D.A.; Slininger, P.J.; Behle, R.W.; Jackson, M.A. Formulation of Bacillus spp. for biological control of plant diseases. Phytopathology 2004, 94, 1267-1271. [CrossRef]

51. Jangir, M.; Sharma, S.; Sharma, S. Development of next-generation formulation against Fusarium oxysporum and unraveling bioactive antifungal metabolites of biocontrol agents. Sci. Rep. 2021, 11, 22895. [CrossRef] [PubMed]

52. Abadias, M.; Usall, J.; Teixidó, N.; Viñas, I. Liquid formulation of the postharvest biocontrol agent Candida sake CPA-1 in isotonic solutions. Phytopathology 2003, 93, 436-442. [CrossRef] [PubMed] 
53. Cheng, H.; Linling, L.I.; Juan, H.; Honghui, Y.; Cheng, S. A preliminary preparation of endophytic bacteria CE3 wettable powder for biological control of postharvest diseases. Not. Bot. Horti Agrobot. 2015, 43, 159-164. [CrossRef]

54. Lahlali, R.; Peng, G.; McGregor, L.; Gossen, B.D.; Hwang, S.F.; McDonald, M. Mechanisms of the biofungicide Serenade (Bacillus subtilis QST713) in suppressing clubroot. Biocontrol Sci. Technol. 2011, 21, 1351-1362. [CrossRef]

55. Samaras, A.; Roumeliotis, E.; Ntasiou, P.; Karaoglanidis, G. Bacillus subtilis MBI600 promotes growth of tomato plants and induces systemic resistance contributing to the control of soilborne pathogens. Plants 2021, 10, 1113. [CrossRef] [PubMed]

56. Venkateswarulu, N.; Shameer, S.; Bramhachari, P.V.; Basha, S.; Nagaraju, C.; Vijaya, T. Isolation and characterization of plumbagin (5-hydroxyl-2-methylnaptalene-1,4-dione) producing endophytic fungi Cladosporium delicatulum from endemic medicinal plants. Biotechnol. Rep. 2018, 20, e282. [CrossRef]

57. Qiao, J.; Yu, X.; Liang, X.; Liu, Y.; Borriss, R.; Liu, Y. Addition of plant-growth-promoting Bacillus subtilis PTS-394 on tomato rhizosphere has no durable impact on composition of root microbiome. BMC Microbiol. 2017, 17, 131. [CrossRef] 